\title{
HERBERT SIMON E OS LIMITES DO CRITÉRIO DE EFICIÊNCIA NA NOVA ADMINISTRAÇÃO PÚBLICA
}

\author{
HERBERT SIMON AND EFFICIENCY CRITERION LIMITS IN THE NEW PUBLIC ADMINISTRATION \\ HERBERT SIMON Y LOS LÍMITES DEL CRITERIO DE EFICIENCIA EN LA NUEVA ADMINISTRACIÓN PÚBLICA
}

\section{Resumo}

Neste ensaio, vamos discutir sobre os limites do critério de eficiência, que é indicado como balizador das decisões de gestão ou políticas públicas. Abordaremos seus limites a partir dos conceitos apresentados por Herbert Simon, que se consagrou por estabelecer os limites da racionalidade nas decisões, até então compreendida como absoluta. Simon defende a necessidade de ampliação do conceito de eficiência, principalmente quando se trata de utilizá-lo na gestão pública, já que ela não deveria se pautar exclusivamente pela dimensão econômico-financeira e incluir outras escalas de valores. Para isso, discutiremos como o critério de eficiência se tornou central na administração pública gerencial e como ele ainda continua se pautando pelo ideal da eficiência absoluta. Em seguida, retomaremos as elaborações de Herbert Simon em Comportamento Administrativo, para evidenciar a inadequação da utilização do critério de eficiência apregoado pela nova administração pública, inserindo o conceito de eficiência relativa.

Palavras-chave: Eficiência, Nova administração pública, Administração pública gerencial, Racionalidade limitada, Herbert Simon.

Kamila Pagel de Oliveira - kamila.oliveira@fjp.mg.gov.br

Doutoranda em Administração pela UFMG, mestre em Administração pela UFMG e Graduada em Administração Pública pela Fundação João Pinheiro. Sub-coordenadora do Curso de Graduação em Administração Pública da Escola de Governo da Fundação João Pinheiro.

Ana Paula Paes de Paula - appp.ufmg@gmail.com

Bacharel em Administração de Empresas pela Universidade de São Paulo, Mestre em Administração Pública e Governo pela Fundação Getulio Vargas - SP e Doutora em Ciências Sociais pela Universidade Estadual de Campinas. Professora Titular e pesquisadora do CEPEAD-UFMG, atuando como subcoordenadora do Núcleo de Estudos de Gestão Pública (NEGP) e do Núcleo de Estudos Organizacionais e Sociedade (NEOS).

Artigo submetido no dia 05.11.2013 e aprovado em 30.05.2014 


\begin{abstract}
This essay, discusses the limits of efficiency criterion indicated as reference in management decisions or public policies. These limits are approached based on the concepts presented by Herbert Simon, who has established rationality limits in decisions, hitherto understood as absolute. Simon defends the need to magnify the concept of efficiency mainly for public management area, since this should not be exclusively oriented to the economic-financial dimension and should include other scales of values. In this context, we discuss how criterion efficiency became central in managerial public administration and how it is based on the ideal absolute efficiency. Then, Herbert Simon ideas in Administrative Behavior are reviewed, to evidence the inadequacy of using the criterion of efficiency hyped by the new public administration, adding to the discussion the concept of relative efficiency.
\end{abstract}

Keywords: Efficiency, New Public Management, Managerial Public Administration, Management, Bounded Rationality, Herbert Simon

\title{
Resumen
}

En este ensayo, se discuten los límites del criterio de eficiencia, referido a las decisiones de gestión de bases o políticas. Discute sus límites a partir de los conceptos presentados por Herbert Simon, que fue consagrado para establecer los límites de la racionalidad en las decisiones hasta ahora entendida como absoluta. Simon defiende la necesidad de ampliar el concepto de eficiencia, especialmente cuando se trata de usarlo en la gestión pública, ya que no debe basarse únicamente en la dimensión económico-financiera y de incluir otras escalas de valores. Para ello, vamos a discutir cómo el criterio de eficiencia se convirtió en el centro de la gestión de la administración pública y cómo todavía es quiado por el ideal de la eficiencia absoluta. A continuación se reanuda las elaboraciones de Herbert Simon en el Comportamiento Administrativo, para poner de relieve la insuficiencia de la utilización del criterio de la eficiencia promocionado por la nueva administración pública, introduciendo así el concepto de eficiencia relativa.

Palabras-Clave: Eficiencia, Nueva Administración Pública, Administración Pública Gerencial, Racionalidad Limitada, Herbert Simon

\section{Introdução}

A nova administração pública, também conhecida como administração pública gerencial, configura-se como um conjunto de ações implementadas em diversos países, a partir da década de 1980, como resposta à crise do Estado, em suas dimensões fiscal, burocrática e intervencionista, que se manifestou em várias partes do mundo nessa época. Com essa crise, administrações públicas de vários países passaram a estabelecer um conjunto de medidas que visavam ao ajustamento das contas públicas e à melhoria na prestação dos serviços públicos (Pereira, 1998; Ferreira, 1999).

Por meio da introdução de ferramentas e técnicas oriundas da iniciativa privada, buscou-se no setor público a modernização da gestão, de modo que a eficiência passou a ser compreendida como uma nova palavra de ordem. No contexto da nova administração pública, a eficiência destaca-se pela necessidade de adequar meios e fins, ou seja, recursos financeiros, humanos ou materiais, com os objetivos pretendidos pelas políticas públicas. Busca-se assim uma boa prática de gestão, de modo que o critério de eficiência se alia a outros princípios, como a descentralização, a gestão por resultados e a flexibilização.

No entanto, alguns autores apontam diversos limites da nova administração pública, afirmando que ela reforça a separação entre política e administração, não considera a dimensão sociopolítica da gestão e se configura como pouco democrática (Paula, 2005; Gomes, 2009). Além disso, questiona-se o que seria eficiência no contexto da gestão pública e se deveria ser parametrizada 
pelos mesmos critérios da gestão empresarial. Neste ensaio, vamos discutir sobre os limites do critério de eficiência, que é indicado como balizador das decisões de gestão ou políticas públicas.

Abordaremos os limites do critério de eficiência a partir dos conceitos apresentados por Herbert Simon, que se consagrou por estabelecer a teoria da racionalidade limitada no processo decisório. A racionalidade até então era compreendida como absoluta e perfeita, de modo que, em decorrência disso, ocorreria também uma busca pela eficiência perfeita no contexto da administração. Simon defende a necessidade de ampliação do conceito de eficiência, principalmente quando se trata de utilizá-lo na gestão pública, já que ela não deveria se pautar exclusivamente pela dimensão econômico-financeira e incluir outras escalas de valores, além de abandonar sua pretensão de perfeição. Suas recomendações para o setor público apontam para a possibilidade de se elaborar um conceito de eficiência relativa, posição que exploramos neste ensaio.

Para isso, discutiremos como o critério de eficiência se tornou central na administração pública gerencial e como ele ainda continua se orientando pelo ideal da eficiência perfeita. Em seguida, retomaremos as elaborações de Herbert Simon (1957) em seu clássico Administrative behavior, originalmente publicado em 1947, para evidenciar a inadequação do uso do critério de eficiência apregoado pela nova administração pública, inserindo o conceito de eficiência relativa, que foi deixado inacabado pelo autor.

\section{A nova gestão pública e a busca pela efici- ência}

A reforma do Estado, que se tornou tema revisto na década de 1980, pode ser interpretada como uma resposta à crise pela qual estava passando, no contexto de uma economia globalizada. A redução da autonomia do Estado na formulação e implantação de políticas públicas, provocada pelo processo de globalização e pela crise econômica e fiscal, sinalizou a necessidade de redefinir suas funções, tornando fundamental a reforma subsequente (Pereira, 1998).

A alternativa para a superação dessa crise financeira e de desempenho se manifestou na necessidade de transformação do Estado e na revisão de suas funções e de seus papéis e mecanismos de funcionamento. Essas transformações foram consolidadas na reforma gerencial do Estado, cujo objetivo foi conferir a ele, maior capacidade de governança e de atuação econômica, política e social, a partir da promoção de uma gestão eficiente dos recursos públicos e da garantia dos direitos sociais e necessidades dos cidadãos (Ferreira, 1999).

Inserida no contexto da reforma do Estado, a administração pública gerencial apresentou-se como alternativa à superação da crise do modelo burocrático, mediante a introdução, no âmbito da administração pública, de mecanismos de gestão característicos da administração de empresas privadas. De acordo com Paula (2005), toma-se, inadequadamente, como premissa, o fato de que o setor privado é mais eficiente que o setor público na proposição e aplicação de decisões administrativas, motivo pelo qual se incentiva a transposição de práticas gerenciais típicas daquele para este.

De maneira abrangente, a reforma gerencial tinha por objetivos: reduzir os custos do Estado, auxiliando no alcance do ajuste fiscal, e modernizar as formas de administrar os recursos públicos para tornar o Estado mais eficiente e voltado ao atendimento das demandas da sociedade. Para 
enfrentar a crise de governabilidade e de governança, a falta de recursos e a redução do poder do Estado, além da ineficiência do modelo burocrático, segundo Abrucio (1997, p. 7):

O aparato governamental precisaria ser mais ágil e mais flexível, tanto em sua dinâmica interna como em sua capacidade de adaptação às mudanças externas. Corte de gastos - inclusive pessoal - aumento da eficiência e atuação mais flexível do aparato burocrático, tudo isto estava contido na cartilha do modelo gerencial [...].

A partir de então, dissemina-se a denominada nova administração pública, ou administração pública gerencial, cujo principal objetivo é minimizar as falhas do modelo burocrático de gestão mediante a aplicação de práticas gerenciais. A nova administração pública emerge, nesse sentido, com a missão de romper com a crise fiscal, a forte cultura patrimonialista dominante na administração pública, o baixo desempenho na prestação de serviços à sociedade e a deficiência na qualidade e quantidade desses serviços (Abrucio, 1997).

A literatura sobre o tema aponta como fundamentos da nova administração pública: descentralização administrativa e delegação de autoridade; redução dos níveis hierárquicos nas organizações; flexibilização dos mecanismos de gestão e dos processos organizacionais; controle por resultados, e primazia pela qualidade do serviço público prestado aos cidadãos. A administração pública gerencial pretende proporcionar aos gestores maior autonomia e realizar o acompanhamento e fiscalização de programas e projetos, enfatizando os resultados das políticas públicas, diferentemente do controle de processos e procedimentos característico do modelo weberiano (Gomes, 2009).

De acordo com Gomes (2009), esse modelo tem, na busca de maior eficiência na administração pública, um dos objetivos cruciais. Assim, o autor afirma que não obstante as divergências inconciliáveis entre as perspectivas de um Estado mínimo e de um Estado adequado, enfatizadas a partir de sua crise no que tange às premissas, causas e soluções para os problemas vivenciados pelas administrações públicas, a questão da eficiência como melhor critério para a realização das políticas e dos serviços públicos é corroborada por ambos, fazendo com que o objetivo da eficiência permanecesse presente, apesar de muitas iniciativas com tal intento terem sido frustradas. $\mathrm{O}$ modelo da administração pública gerencial contempla o valor da eficiência, pois visualiza a necessidade de definição dos objetivos e sua operacionalização em resultados, e ainda em flexibilidade quanto aos recursos e processos, o que permite uma adequação mais racional aos fins visados.

A partir da década de 1980, não obstante a disseminação do modelo proposto pela administração pública gerencial por diversos governos, algumas críticas e limitações a ele são apontadas por vários autores. De acordo com Rhodes (1996), a nova administração pública apresenta como principais fraquezas os seguintes pontos: 1) foco intraorganizacional, uma vez que concede pouca atenção ao interorganizacional e a negociação e compartilhamento de recursos e objetivos; 2) obsessão por objetivos, pois estimula a competição por incentivo e deixa em segundo plano a cooperação e confiança necessárias para a governança; 3) foco em resultados, mas há problemas para a identificação de quem os alcança; 4) baixo nível de interdependência entre os atores e a sociedade civil, muitas vezes, originado pela reduzida confiança para 
negociação e participação.

$\mathrm{Na}$ mesma direção, Denhardt e Denhardt (2000) afirmam que as preocupações da nova administração pública se focalizam na introdução de técnicas e valores da administração privada no contexto do setor público. Nesse sentido, a busca pelo espírito empreendedor na gestão pública muitas vezes concede ao gestor uma posição hegemônica como detentor dos recursos, fazendo com que a decisão quanto à sua boa utilização seja responsabilidade unicamente dele, o que contraria a necessidade de negociação e articulação entre diversos atores e a sociedade civil. Assim, esses autores sugerem que o governo deveria ser partilhado com os cidadãos; logo, eles deveriam ser empoderados para participar do processo de definição e implementação de políticas públicas, em vez de obliterados em sua participação pelos gestores públicos.

Paula (2005) também caminha nessa direção e afirma ainda que a nova administração pública não enfrenta a complexidade da gestão pública à medida que focaliza predominantemente a busca pela eficiência do governo, esquecendo-se da inclusão efetiva da dimensão sociopolítica, o que reforça a separação entre política e administração. Assim, o Estado gerencial preconizado pela nova administração pública enfatiza a boa gestão, mas não contempla a resolução dos conflitos e das contradições sociais.

Diante do exposto, tem-se que, a partir da nova administração pública, pretende-se solucionar os problemas de governo identificando como solução primordial para eles a busca por eficiência. O que pretendemos apontar neste ensaio é que há diversos limites para o alcance da eficiência, que envolvem fatores políticos, organizacionais, culturais, psicológicos e que, de certa forma, estão imbricados nas próprias limitações da racionalidade, definidas por Simon (1945).
Passaremos, então, à análise dos limites do critério de eficiência no contexto da administração, apresentados por Herbert Simon, e à crítica realizada por ele sobre a eficiência perfeita para delinear um conceito de eficiência relativa. Ao longo desta análise também evidenciaremos a inadequação do critério de eficiência quando se trata de questões valorativas, que são fundamentais no setor público e as limitações da administração pública gerencial, ao insistir no predomínio dos fatos em detrimento dos valores.

\section{Os limites do critério de eficiência, a par- tir de Herbert Simon, e os impactos na nova administração pública}

Atuando como economista, cientista político e psicólogo, Herbert Simon destacou-se como um dos grandes pensadores do século XX. Sua importância foi reconhecida nos estudos organizacionais em decorrência de suas significativas afirmações a respeito do processo decisório. Em 1978, Simon ganhou o Prêmio Nobel de Economia por ter elaborado uma teoria acerca do comportamento e do processo de decisão na organização, que colocava em questão os pressupostos da economia neoclássica, a partir da identificação dos limites da racionalidade.

Seu trabalho está sendo resgatado atualmente por pesquisadores que fazem uma releitura de sua obra e enfatizam a crítica que realiza sobre a economia neoclássica e a administração clássica. Como evidencia Balestrin (2002), o Nobel se deveu ao fato de Simon questionar a economia convencional da teoria da oferta e demanda, pois suas elaborações trazem a complexidade do mundo real por meio da psicologia e da ciência comportamental. Balestrin 
(2002, pp. 4-5), afirma que Simon apresentou:

[...] a teoria da racionalidade limitada, em que contrapunha a visão clássica de que os administradores sempre tomam decisões que maximizam lucros e que os indivíduos sempre fazem a melhor escolha entre numerosas alternativas. Simon observou que o processamento de informações pelas pessoas é limitado e geralmente busca-se uma aproximação satisfatória dos resultados.

Para Simon (1957, p. XXIV), a teoria administrativa é a uma teoria da racionalidade intencional e limitada dos seres humanos:

The central concern of administrative theory is with the boundary between the rational and the non-rational aspects of human social behavior. Administrative theory is peculiar the theory of intended and bounded rationality of the behavior of human beings who satisface because they have not the wits to maximize (grifos nossos).

Assim, para Simon (1957) os agentes não maximizam, pois não há sagacidade o bastante para isso, mas contemporizam. $\mathrm{O}$ termo originalmente utilizado por Herbert Simon é satisfice, que é uma combinação de satisfy e sacrifice, no sentido de que o homem administrativo satisfaz a alguns critérios e sacrifica outros. $\mathrm{Na}$ edição brasileira, o termo foi traduzido como contemporizar. Simon (1957, p. XXV) contrapõe-se ao homem econômico da economia neoclássica, que maximiza seus esforços e seleciona a melhor alternativa; o homem administrativo, que contemporiza, ou seja, que busca uma ação satisfatória ou razoavelmente boa. Em suas palavras: While economic man maximizes - selects the best alternative from among all those available to him; his cousin, whom we shall call administrative man, satisfaces looks for a course of action that is satisfactory or "good enough".

Simon (1957) esforça-se para deslocar a ideia de maximização colocando em seu lugar o conceito de contemporização. Seu texto sugere a inviabilidade da maximização devido à impossibilidade lógica, pois, para que isso fosse uma realidade, o agente deveria ser capaz de avaliar todas as alternativas possíveis antes de tomar uma decisão. Assim, mesmo quando o agente crê que maximiza, na realidade contemporiza. A intencionalidade de maximização pode até prevalecer, mas o fato é que não há garantia de que ela ocorra, pois sempre existe a possibilidade de que outras alternativas de tomada de decisão levem ao melhor resultado.

First, because he satisfaces, rather than maximizes, administrative man can make his choices without first examining all possible behavior alternatives. Second, because he treats the world as rather "empty", and ignores the "interrelatedness of all things" (so stupefying to thought and action), administrative man is able to make his decisions with relatively simples rules of thumb that do not make impossible demands upon his capacity for thought (Simon, 1957, p. XXVI).

Em seu discurso para o Prêmio Nobel em 1978, Simon (1979, p. 497) tenta evidenciar novamente que contemporização reflete melhor as evidências empíricas do que a maximização e faz isso recorrendo a exemplos práticos:

It would take a much more extensive review than is provided here to establish the point 
conclusively, but I believe it is the case that specific phenomena requiring a theory of utility or profit maximization for their explanation rather than a theory of bounded rationality simply have not been observed in aggregate data. In fact, as my last two examples indicate, it is the classical rather than the behavioral form of the theory that faces real difficulties in handling some of the empirical observations.

Nesse discurso, Simon (1979, p. 504) procura defender mais uma vez sua tese de contemporização, mas admite as resistências dos economistas quanto ao abandono da "perfeita maximização", pois, em sua visão, mesmo nas teorias mais recentes, o apego a tal noção permanece. Sua insistência nesse ponto reforça suas críticas quanto à adequação da maximização para explicar e gerir o processo decisório, uma vez que ele chega a afirmar que os economistas continuam se iludindo quanto à possibilidade de lidar efetivamente com toda a informação e incerteza implicada em uma decisão.

In none of these theories any more than in statistical decision theory or the theory of games is the assumption of perfect maximization abandoned. Limits and costs of information are introduced, not as psychological characteristics of the decision maker, but as part of his technological environment. Hence, the new theories do nothing to alleviate the computational complexities facing the decision maker do not see him coping with them by heroic approximation, simplifying and satisficing, but simply magnify and multiply them. Now he needs to compute not merely the shapes of his supply and demand curves, but, in addition, the costs and benefits of computing those shapes to greater accuracy as well. Hence, to some extent, the impression that these new theories deal with the hither- to ignored phenomena of uncertainty and information transmission is illusory. For many economists, however, the illusion has been persuasive.

As colocações de Simon sobre maximização têm repercussões no tratamento que faz do conceito de eficiência. De acordo com Simon (1957, p. 179), o princípio norteador da teoria administrativa tem sido o critério de eficiência que determina [...] that choice of alternatives produces the largest result for the given application of resources. Trata-se, portanto, de uma relação entre meios e fins, entre recursos utilizados em determinada ação e fins pretendidos com ela. Nas organizações privadas, esse critério é mais facilmente compreendido, pois se refere ao lucro, ou seja, a eficiência nessas organizações significa a escolha da alternativa que gera a maior receita líquida (em termos monetários) para a organização, maximizando receita ou minimizando custos. No entanto, a aplicação do critério de eficiência é bem mais complexa nas organizações não comerciais, nas quais a medida monetária dos resultados costuma ser insignificante, ou mesmo impossível. Assim, torna-se necessário ampliar o conceito quando aplicado a elas.

The simplicity of the efficiency criterion in commercial organizations is due in large part to the fact that money provides a common denominator for the measurement of both output and income, and permits them to be directly compared. The concept must be broadened, therefore, if it is to been applicable to the process do decision where factors are involved that are not directly measurable in monetary terms. Such factors will certainly be present in non-commercial organiza- 
tions where monetary measurement of output is usually meaningless or impossible (Simon, 1957, p. 173) (grifo nosso).

As organizações públicas seriam um exemplo disso, mas o autor ressalta que há limitações desse uso inclusive em organizações privadas, já que elas também se preocupam, muitas vezes, com o interesse público e a satisfação dos funcionários, ou com questões que não podem ser estritamente contabilizadas em termos monetários. Pode-se pensar também, como exemplo, na atual preocupação das organizações com a responsabilidade social e ambiental.

[the factors]... will also be present in commercial organizations to the extent that those controlling the organization are not solely directed toward the profit motive - i.e. where they are concerns of the public interest or employee welfare even when those factors are not directly related to the profit and loss statement. Moreover, nonmonetary factors will also be involved in the internal operation even of purely commercial organizations where specific activities are concerned whose relation to the profit-and-loss statement cannot be assessed directly. For example, decisions in a personnel department cannot always be evaluated in monetary terms, because the monetary effect of particular policy cannot be directly determined (Simon, 1957, p. 173).

Considerando as organizações públicas, nas quais os fatores não devem ser exclusivamente mensurados em termos monetários, a tomada de decisões torna-se um dilema devido à intangibilidade dos serviços públicos.

[...] the values which public services seek to realize are seldom expressible in concrete terms. Aims, such as those of a recreation department - to "improve health", "provide recreation", "develop good citizens" - must be stated in tangible and objective terms before results can be observed and measured. A serious dilemma is posed here. The values toward which these services should be directed do not provide sufficiently concrete criteria to be applied to specific decisional problems (Simon, 1957, p. 176).

Simon (1957, p. 176) argumenta que o substituto do valor monetário de produção na administração pública deveria ser encontrado na formulação de índices de valores que medem o grau de consecução dos objetivos de uma ação governamental, de modo que fosse possível comparar resultados de diferentes cursos de ações. O problema é que há uma dificuldade considerável para definir objetivos no setor público, pois, quando procuramos expressá-los em valores, frequentemente constatamos que eles são pouco tangíveis.

Isso cria uma dificuldade nos processos decisórios, pois, quando se trata de decisões financeiras, comparam-se dois cursos de ação diferentes para escolher o melhor resultado monetário, sendo que, se os dois levam ao mesmo resultado monetário, é indiferente escolher entre um e outro. No caso de decisões que envolvem políticas públicas, entre dois cursos de ações diferentes, são raras as vezes que se pode dizer que um leva a um resultado melhor do que o outro, ou que cheguam aos mesmos resultados, pois aqui os resultados obtidos são qualitativamente muito diferentes e não mensuráveis em termos monetários.

Assim, Simon (1957) aponta que a impossibilidade de fazer uma comparação absolutamente tangível entre duas decisões 
torna o critério de eficiência limitado para o setor público, ou para situações em que o efeito monetário de um resultado não pode ser determinado. Ele reconhece que, na visão do gestor, o critério de eficiência determina alternativas que conduzem à maximização de resultados na aplicação de determinados recursos. No entanto, questiona a efetividade do conceito, na medida em que ele não resolve e nem evita o problema da comparabilidade:

It should be noted that this criterion, while it supplies a common denominator for the comparison of administrative alternatives, does not supply a common numerator. Even though all decisions be made in terms of alternative applications of the same resources, the problem still remains of comparing the values which are attained by the different courses of action. The efficiency criterion neither solves nor avoids this problem of comparability (Simon, 1957, pp. 179-180).

Ocorre, nesse caso, uma importante limitação nas recomendações da administração pública gerencial, já que ela preconiza o critério da eficiência como o fator fundamental a ser buscado, sem problematizar o que seria eficiência nesse contexto. Questionamos se a administração pública gerencial, aliada à sua preocupação com a eficiência, não está deixando de lado o substancial, que deveria estar relacionado à definição democrática dos valores a serem perseguidos, pois se preocupa primordialmente com a eficiência em sua definição de adequação de meios e fins, em vez de priorizar a definição desses fins e selecionar os critérios.

Originalmente, segundo Simon (1957, p. 180), o termo eficiência era definido como fitness or power to accomplish, or success in accomplishing, the purpose intended; adequate power, effectiveness, efficacy, de modo que eficiência era quase um sinônimo de efetividade.
No entanto, mais recentemente, a eficiência adquiriu um segundo significado, que é a relação entre fatores (input) e produto (output), como definida na Encyclopedia of the Social Sciences, citada por Simon (1957, p. 180):

Efficiency in the sense of ratio between input and output, effort and results, expenditure and income, cost and resulting pleasure, is a relatively recent term. In this specific sense it became current in engineering and during the latter half of the nineteenth century and in business and in economics only since beginning of the twentieth.

Simon (1957, p. 181), então, afirma que o problema é que, em geral, se considera o conceito de eficiência perfeita advindo das ciências físicas e da engenharia nas ciências sociais, mas não há como se ter uma eficiência absoluta:

It must be noted that there is a difference in computing an output-input ratio in the physical and in the social sciences. For the engineer, both output and input are measured in terms of energy. The law of conservation of energy tells him that the output of useful energy cannot exceed the energy input. Hence arises the concept of "perfect" efficiency - that is, a situation in which output equals input. In social sciences, output and input are seldom measured in comparable units; and even when they are, [...], there is no "law of conservation of energy" which prevents the output from exceeding the input. Hence, the concept of perfect efficiency, if it is used at all, must be redefined. As a matter of fact, the concept of perfect efficiency will not be required in the 
present study. Actual problems, as they present themselves to the administrator, are always concerned with relative efficiencies, and no measure of absolute efficiency is ever needed (grifos nossos).

Para Simon (1957), na realidade, o administrador não escolhe entre a mais eficiente de duas possibilidades alternativas, mas entre as eficiências possíveis dessas duas possibilidades. Não se trata de uma eficiência perfeita, mas de eficiências relativas, de modo que, no contexto da administração, o conceito de eficiência deveria ser redefinido e ampliado. Valendo-se das considerações feitas pelo autor, tomaremos o conceito de eficiência perfeita para distinguir a noção eficiência comumente considerada na administração do conceito de eficiência que Simon tenta construir em Administrative Behavior. Por esse motivo, a seguir, utilizaremos o termo eficiência perfeita toda vez que nos referirmos à eficiência sugerida a partir dos moldes da administração clássica e denominaremos como eficiência relativa o conceito ressignificado com base no pensamento de Simon.

Indo além, Simon (1957, p. 182) evidencia como a noção de eficiência perfeita trazida da física para as ciências sociais tem seu equivalente na economia e na administração, mas traduzida no conceito da maximização da utilidade:

It can be seen that the criterion of efficiency as applied to administrative decisions is strictly analogous to the concept of maximization of utility in economic theory. It is not asserted here that the criterion of efficiency always does dominate administrators, decisions, but rather that if they were rational it would. There is no assertion that such rationality is a common characteristic of actual behavior. On the other hand, the doctrine of maximization of utility has been commonly set forth in the economic literature as a explanatory doctrine as well, that is, as descriptive of actual behavior in the market. This difference between the two propositions should be kept carefully in mind (Simon, 1957, p. 182).

Apesar dessas limitações, seguindo as recomendações da nova administração pública que se inspira na lógica da gestão empresarial, o alcance da eficiência perfeita, traduzido na administração como a busca por escolhas que utilizem a menor quantidade de recursos possíveis e maximizem os resultados, pauta de grande parte das ações públicas, quando a prioridade deveria ser os valores que orientam os objetivos e resultados. Embora haja dificuldade de comparabilidade entre políticas de diferentes áreas, ainda recorre-se constantemente, como balizador das decisões, à eficiência perfeita, não utilizada por Simon (1957) em seu estudo por ser considerada inadequada para a administração.

Uma limitação presente no critério de eficiência perfeita refere-se ao fato de que, para se afirmar que alguma ação, é, será ou foi eficiente, é necessário identificar uma perfeita relação entre os recursos empregados nessa ação e os resultados alcançados por ela. No entanto, as políticas públicas estão permeadas por relações entre variáveis nas quais não há possibilidade de comprovação de relação de causa e efeito. No setor público, não há como determinar com precisão que um resultado de uma política pública foi alcançado em decorrência de uma ação específica.

A redução da mortalidade infantil, por exemplo, pode estar associada a uma ação da área da saúde, como a realização de cam- 
panhas de vacinação, mas também a grandes investimentos realizados pelo governo no saneamento básico. De forma semelhante, a redução da criminalidade pode relacionar-se ao maior policiamento, a ações que aproximem os alunos da escola ou ainda a ações de cultura e esporte. Logo, a utilização do critério de eficiência perfeita como balizador de uma decisão apresenta limitações, uma vez que nem sempre é possível a comprovação da relação direta entre recursos e fins.

Por outro lado, o governo lida constantemente com demandas diversas, em diferentes setores e de grupos variados, de modo que a impossibilidade de comparação exata entre as diferentes prioridades dificulta a aplicação do critério de eficiência perfeita. Além da incomparabilidade dos diferentes valores, tem-se ainda, na administração pública, uma dificuldade para definir os objetivos das ações públicas, já que eles representam valores pouco tangíveis e objetivos múltiplos. Assim, outra dificuldade ocorre, pois, ainda que fosse possível elencar as alternativas de ações que se utilizam do mesmo recurso e comparar os diferentes valores, a escolha dos objetivos a serem alcançados envolve julgamentos de valor, enquanto o critério de eficiência perfeita, tal como tem sido disseminado, é neutro, ou seja, não contempla a presença dos valores nas decisões.

De acordo com Simon (1957), o critério da eficiência tem sido criticado pelo fato de separar meios e fins. Além disso, aponta para um processo decisório com base no factual, que torna a eficiência restrita e mecânica, pois critérios de natureza ética também deveriam ser aplicados ao problema da decisão.

Common to all these criticisms is an implication that an "efficiency" approach involves a complete separation of "means" and "ends". We have already seen that, strictly speaking, this is not the case - that the only valid dis- tinction is one between ethical and factual elements in decision. Yet, in the actual application of efficiency criterion to administrative situations, there is often a tendency to substitute the former distinction for the latter, and such a substitution inevitably results in the narrower, "mechanical" efficiency, which has been the subject of criticism (Simon, 1957, p. 184).

Tais critérios éticos tendem a ser deixados em segundo plano pela nova administração pública, já que ela preconiza a neutralidade da administração e reforça a separação entre ela e política. Conforme discutido anteriormente, a administração pública gerencial tende a não considerar os aspectos sociopolíticos da administração pública, o que significa, entre outras coisas, ignorar exatamente as diferenças e os conflitos na definição dos valores que permeiam os fins, que devem ser alcançados pela gestão pública, colocando o foco no factual e não no ético.

Para Simon (1957), tomadas as decisões, os administradores públicos, em geral, ignoram sua responsabilidade pelos resultados indiretos de suas atividades administrativas, enfatizando a eficiência perfeita em detrimento dos critérios éticos. O autor é contrário a essa prática, pois afirma que um critério de eficiência válido para um governo democrático deveria incluir uma postura valorativa do administrador, ainda que as limitações à racionalidade dificultem isso:

To this point of view we oppose the contrary opinion that the administrator, serving a public agency in a democratic state, must give a proper weight to all community values that are relevant to his activity, and that are reasonably ascer- 
tainable in relation thereto, and cannot restrict himself to values that happen to be his particular responsibility. Only under these conditions can a criterion of efficiency be validly postulated as a determinant of action. Of course the extent to which administrators can, in practice, give consideration to "indirect" effects is severely limited by the psychological considerations analyzed at length in Chapter V. Many effects not directly related to the objective organization will perforce be ignored because the administrator's span of attention is limited, and because there are often severe limits on the time available for making decisions (Simon, 1957, p. 186) (grifo nosso).

Simon (1957) conclui que, no que se refere aos aspectos factuais da tomada de decisões, o administrador deve se orientar pelo critério da eficiência, mas, quanto aos aspectos valorativos, esse critério não faz sentido, de modo que a distinção entre valor e fato é fundamental na administração pública:

[...] in the factual aspects of decision-making, the administrator must be guided by the criterion of efficiency. This criterion requires that results be maximized with limited resources. On the other hand, criteria of "correctness" have no meaning in relation to the purely valuational elements in decision. A democratic state is committed to popular control over theses value elements, and the distinction of value from fact is of basic importance in securing a proper relation between policy-making and administration.

Diferenciar administração de economia é uma das tentativas de Simon (1957, pp. 240-241), que se esforça para evidenciar que a administração não consiste no preceito único da maximização de resultados justamente porque a racionalidade é limitada. Se a tarefa da administração fosse somente essa, não haveria necessidade de teorias administrativas, pois bastaria o utilitarismo econômico.

[...] if there were no limits to human rationality administrative theory would be barren. It would consist of the single precept: Always select that alternative, among those available, which will lead to the most complete achievement of your goals. The need for an administrative theory resides in the fact that there are practical limits to human rationality, and that limits are not static, but depend upon the organizational environment in which the individual's decision takes place (grifo nosso).

Por fim, a utilização do critério de eficiência perfeita como pressuposto da administração pública gerencial enfrenta os limites da própria racionalidade. No pensamento de Simon (1957), é central a existência de um conjunto de limitações da racionalidade que interferem no comportamento administrativo e na tomada de decisão, limites esses relacionados às capacidades física, cognitiva e de recursos do indivíduo, aos valores e conceitos de finalidades que influenciam o tomador de decisão e à extensão de seu conhecimento. Em suas palavras:

Rationality implies a complete, and unattainable knowledge of the exact consequences of each choice. In actuality, the human being never has more than a fragmentary knowledge of conditions surrounding his action, nor more that a slight insight into the regularities and laws that would permit him to induce future consequences from a knowledge of present circumstances (Simon, 
1957, p. 80).

Dessa forma, não obstante a busca pela eficiência perfeita estar adequada às bases da nova administração pública, que coaduna com a racionalidade instrumental e com o pressuposto do homem econômico, o reconhecimento dos limites dessa racionalidade e a aceitação do homem administrativo como aquele dotado de características mais realistas do que o homem econômico, coloca em questão a adequação do critério de eficiência trazido, a partir da gestão empresarial, pela administração pública gerencial para lidar com a complexidade da gestão pública. Em síntese, as formulações de Herbert Simon nos permitem especular que, para a administração pública, o critério de eficiência deveria ser relativo, ou seja, no processo decisório do setor público, é necessário relativizar os aspectos factuais de acordo com os elementos valorativos em jogo, que estão submetidos ao controle popular.

\section{Considerações finais}

A administração pública configura-se com o aparelhamento do Estado, preordenado à realização de seus serviços e políticas públicas que visa à satisfação das necessidades coletivas. Administrar significa, ainda, gerir os recursos públicos, o que contempla realizar políticas públicas e também dirigir, governar e cumprir a vontade da sociedade com o objetivo de obter resultados úteis.

O alcance dessa finalidade da administração pública não é, portanto, tarefa fácil, pois ela possui diversas características que a tornam complexa e dificultam o processo de tomada de decisão pelo gestor. A partir da década de 1980, diversos países passaram a implementar um modelo de gestão pública caracterizado pela administração pública gerencial, cujo pressuposto fundamental refere-se à busca de eficiência como critério para o alcance dos objetivos das organizações públicas.

No entanto, percebe-se que o critério de eficiência corrente apresenta várias limitações, tendo em vista que, a partir da perspectiva de Simon (1957), não representa um critério adequado para a tomada de decisão em organizações públicas. No que tange ao setor público, limitações como a dificuldade de identificação dos valores a serem perseguidos, a impossibilidade de considerar a percepção de todos os envolvidos para a escolha dos fins, a falácia da neutralidade das decisões acerca das políticas públicas, a incomparabilidade das políticas que lidam com prioridades distintas e os limites da própria racionalidade foram discutidos como fatores que põem em questionamento o uso de tal critério de eficiência como balizador da tomada de decisão na gestão pública tal como preconizado na administração pública gerencial.

As considerações de Herbert Simon sobre a racionalidade limitada no processo decisório e sua recomendação para ampliação e redefinição do conceito de eficiência, no sentido de indicar a relatividade como elemento fundamental na tomada de decisões na gestão pública, parecem-nos um caminho promissor para construir um novo referencial para instruí-la, de modo que a relação entre os valores envolvidos e os resultados alcançados pudesse ser reequacionada. Este ensaio recoloca o desafio trazido por Simon em seu trabalho, que é construir um conceito de eficiência relativa, que relativize os fatos de acordo com os valores sustentados pelo controle popular, sugerindo que há caminhos para se repensar a forma como as decisões são tomadas nos governos.

\section{Referências}


Abrucio, F. L. (1997). O impacto do modelo gerencial na administração pública: um breve estudo sobre a experiência internacional recente. Cadernos ENAP, 10,1-50.

Balestrin, A. (2002). Uma análise da contribuição de Herbert Simon para as teorias organizacionais. REAd, 8, 4, 1-17.

Denhart, R. B \& Denhart, J. V. (2000). The New Public Service: Serving Rather than Steering. Public Administration Review, 60, 6, 549-449.

Ferreira, C. M. M. (1999). Crise e Reforma do Estado: uma questão de cidadania e valorização do servidor. In: V. Petrucci \& L. Schwarz (Orgs.). Administração Pública Gerencial: a reforma de 1995. Brasília: EdUNB.

Gomes, E. G. M. (2012). Gestão por resultados e eficiência na Administração Pública: uma análise à luz da experiência de Minas Gerais. Tese de doutorado, Escola de Administração de Empresas de São Paulo, Fundação Getulio Vargas, São Paulo, SP, Brasil.
Paula A. P. P. (2005). Por uma nova gestão pública: limites e potencialidades da experiência contemporânea. Rio de Janeiro: EdFGV.

Pereira, L. C. B. (1998). Reforma do Estado para a cidadania: a reforma gerencial brasileira na perspectiva internacional. São Paulo: Editora 34; Brasília: ENAP.

Rhodes, R. A. W. (1996). The New Governance: governing without government. Political Studies, 44, 4, 652-667.

Simon. H. A. (1957). Administrative Behavior: A Study of Decision-Making Processes in Administration Organizations (2a ed.). New York: Macmillan. (Obra original publicada em 1947).

Simon, H. A. (1979). Rational Decision Making in Business Organizations. The American Economic Review, 69, 4, 493-513. 